\title{
Cloning of Rabbit Bone Morphogenetic Protein 15 and Its Expression During in vitro Maturation of Rabbit Oocytes
}

\author{
YIN Ping, JI Jing-qiang, LI Lin, DING Jia-tong ${ }^{*}$ \\ (College of Animal Science and Technology, Yangzhou University, Yangzhou 225009, China)
}

\begin{abstract}
Partial cDNA sequence of rabbit BMP15 was cloned by RT-PCR from rabbit ovaries, showing a similarity of $83 \%-90 \%$ with the BMP15 nucleotide sequences in humans, mice, ovine, sheep, cows and pigs. The expression of BMP15 in rabbit cumulus-oocyte complexs during oocytes in vitro maturation (IVM) was measured by fluorescent quantitative RT-PCR method. BMP15 was expressed at low levels in immature oocytes and increased to the highest level at $16 \mathrm{~h}$ of IVM, which coincides with the time of cumulus cell expansion, then declined slowly under IVM cultivation. The expression pattern of BMP15 suggested that it might be important in cumulus expansion in rabbits.
\end{abstract}

Key words: Rabbit; Bone morphogenetic protein 15; Oocyte; Gene cloning; Fluorescent quantitative RT-PCR

\section{兔骨形态发生蛋白 $15 \mathrm{cDNA}$ 部分序列的克隆及其在卵母细胞中的表达}

\author{
尹萍，季金强，李霖，丁家桐* \\ (扬州大学 动物科学与技术学院, 扬州 225009)
}

摘要：采用 RT-PCR 法从新西兰大白兔卵巢中克隆出 BMP15 基因部分 cDNA 片段, 经 blast 分析后, 发现其 与猪、牛、绵羊、山羊、人和小鼠的同源性达到了 $83 \%$ - $90 \%$ 。同时, 利用实时荧光定量 RT-PCR 方法检测了 BMP15 mRNA 在卵母细胞体外成熟培养过程中（IVM）的表达变化情况, 结果表明: 在兔卵母细胞体外成熟过程中, 该 基因在未成熟卵母细胞中表达水平较低, 在培养 $16 \mathrm{~h}$ 其表达丰度达到峰值, 并与卵丘扩展时间相一致, 随后下降, 推测 BMP15 可能在兔卵丘细胞扩展中发挥重要作用。

关键词: 兔; 骨形态发生蛋白 15; 卵母细胞; 克隆; 菼光定量 RT-PCR
中图分类号: Q344.13; Q785; Q959.837 文献标识码: A 文章编号：0254-5953-(2008)06-0603-05

The bilateral communication between oocytes and follicle cells is important to the growth and maturation of oocytes and subsequent embryo developmental potential. After follicular formation, growth factors secreted by oocytes play important roles in regulation of granulose cell differentiation and cumulus expansion (McNatty et al, 2003; Dragovic et al, 2005). Oocyte-secreted factors (OSFS) can suppress the expression of FSH receptor by modulating steroidogensis and inhibin production to directly modify the functions of cumulus cells including accelerating cell proliferation, preventing apoptosis and inhibiting luteinization (Eppig et al, 2001; Gilchrist et al, 2004; Hussein et al, 2005). It has been proved that bone morphogenetic protein 15 (BMP15) was one of the most important members of OSFs (Eppig et al, 2001; Gilchrist et al, 2004). Dube et al (1998) identified the mouse BMP15 gene. The gene belongs to the TGF- $\beta$ superfamily of growth factors. It is a crucial oocyte-derived growth factor, as evidenced by the reproductive defects in animals with mutations in the gene (Liao et al, 2003; He et al, 2006; Hou et al, 2006) and by the ability of recombinant forms of the growth factor to mimic the actions of the oocyte on granulosa cells and CCs in vitro (Yan et al, 2001).

In this research, RT-PCR was used to clone the coding region of BMP15 from rabbit (Oryctolagus cuniculus) oocytes and its expression level during in vitro maturation (IVM) of oocytes was also studied. 


\section{Materials and Methods}

\subsection{Materials}

1.1.1 Experimental subjects 5-month-old female New Zealand rabbits were purchased from Jinling Rabbit Breeding Farm in Nanjing, China.

1.1.2 Regent Tissue culture medium-199 (TCM-199; Gibco); hyaluronidase (Sigma); RNA extraction regent (Invitrogen); first strand cDNA synthesis kit from Ferentas(MBI); Goldview from SBS Genetech Co Ltd; Biospin was purchased from Ribo Hangzhou Co Ltd; $E$. coli DH5 $\alpha$ stored in our laboratory; pMD19-T and SYBR Premix Ex Taq purchased from Dalian Baosheng Biology Engineering Co Ltd.

\subsection{Methods}

1.2.1 Collection and in vitro maturation of rabbit oocytes Ovaries of six New Zealand rabbits were collected and placed on culture dishes. One of the ovaries was directly used for RNA extraction and the others were washed twice with PBS. Follicles were selected by size (diameter $\geq 2 \mathrm{~mm}$ ) and cumulus-oocyte complexs (COCs) were isolated by puncturing the follicles and collected using a glass pipette from the culture medium. COCs were firmly compacted, multilayered cumulus cells and a uniformly granulated cytoplasm. The culture medium was TCM199, supplemented with $0.2 \mathrm{mmol} / \mathrm{L}$ sodium pyruvate, $100 \mathrm{IU} / \mathrm{mL}$ Penicillin-Streptomycin, 10\% FCS, $10 \mathrm{IU} / \mathrm{mL} \mathrm{FSH}, 10 \mu \mathrm{L} / \mathrm{mL} \mathrm{LH}$ and filtered through a 0.2 $\mu \mathrm{m}$ membrane. COCs were cultured at $38.5^{\circ} \mathrm{C}$ in an incubation chamber infused with $5 \% \mathrm{CO}_{2}, 5 \% \mathrm{O}_{2}$ and $90 \% \mathrm{~N}_{2}$ for $24 \mathrm{~h}$.

1.2.2 Extraction and purification of total RNA $100 \mathrm{mg}$ ovarian tissues were added into $1 \mathrm{~mL}$ Trizol. According to the evaluation standards of cumulus expansion (Prochazka et al, 2004), 60 oocytes were selected from each $0 \mathrm{~h}, 8 \mathrm{~h}, 16 \mathrm{~h}$ and $24 \mathrm{~h}$ samples. Denuded oocytes (DOs) were obtained by removing cumulus cells with $0.1 \%$ hyaluronidase and passing the oocytes through a glass pipette several times, then washed in PBS three times. DOs were transferred to tubes on ice, and RNA was isolated using $800 \mu \mathrm{L}$ Trizol regent.

After the extraction, the RNA was dissolved in $7 \mu \mathrm{L}$ DEPC-treated water and kept at $-70^{\circ} \mathrm{C}$. One microliter of solution was taken for a concentration test by $\mathrm{A}_{260} / \mathrm{A}_{280}$ and $1 \%$ agar gel electrophoresis was used to examine the integrity of RNA. All samples were treated with DNase I to eliminate any contaminating genomic DNA.

1.2.3 First-strand cDNA synthesis According to the manufacturer's instructions, the first strand of cDNAs was synthesized. Eleven microliter of RNA were collected separately from oocytes in tubes at each period, while $6 \mu \mathrm{L}$ RNA were collected from ovaries. One microliter of oligo-dT was added to each tube and diluted to $12 \mu \mathrm{L}$ by DEPC-treated water. The mixture was incubated at $70^{\circ} \mathrm{C}$ for $5 \mathrm{~min}$ to denature RNA, and then chilled on ice. Each solution was added in $5 \times$ RT Buffer 4 $\mu \mathrm{L}$, dNTP $(10 \mathrm{mmol} / \mathrm{L}) 2 \mu \mathrm{L}, 20 \mathrm{U} / \mu \mathrm{L}$ RNase inhibitor and incubated at $37^{\circ} \mathrm{C}$ for $5 \mathrm{~min}$. One microliter of M-MLV was added and extended at $42^{\circ} \mathrm{C}$ for $60 \mathrm{~min}$. The reaction was stopped by heating at $70^{\circ} \mathrm{C}$ for $10 \mathrm{~min}$ and another $5 \mathrm{~min}$ on ice. cDNA was harvested.

1.2.4 Cloning and sequencing of the rabbit BMP15 gene Primers were designed based on the mouse and human sequences in GenBank to amplify part of the rabbit BMP15. Forward primer: 5'-GCTGGGATCACT GGATCATT-3', Reverse primer: 5'-TGTACAGGACTG GGCAATCA-3'.

The primer pair was expected to amplify a 260-bp fragment. Reaction system: ovarian cDNA template $1 \mu \mathrm{L}$, $10 \times$ Buffer $\left(\mathrm{Mg}^{2+}\right.$ Plus) $2 \mu \mathrm{L}$, dNTP $(10 \mathrm{mmol} / \mathrm{L}) 0.5 \mu \mathrm{L}$, $10 \mu \mathrm{mol} / \mathrm{L}$ forward primer $0.7 \mu \mathrm{L}$ and, reverse primer 0.7 $\mu \mathrm{L}, 5 \mathrm{U} / \mu \mathrm{L}$ Taq DNA polymerase $0.5 \mu \mathrm{L}$ diluted by DEPC $\mathrm{H}_{2} \mathrm{O}$ to $25 \mu \mathrm{L}$. The PCR amplification was performed under the following conditions: predenaturation at $94^{\circ} \mathrm{C}$ for $3 \mathrm{~min} ; 30$ cycles of $20 \mathrm{~s}$ at $94^{\circ} \mathrm{C}, 30 \mathrm{~s}$ at $56^{\circ} \mathrm{C}, 20 \mathrm{~s}$ at $72^{\circ} \mathrm{C}$; and a final extension at $72^{\circ} \mathrm{C}$ for 5 min. At the same time, negative control (no template) was set up for comparison. Five microliters of PCR products were visualized by $1 \%$ agarose gel electrophoresis (contains $0.05 \mu \mathrm{L} / \mathrm{mL}$ Goldview), results were recorded using a gel imaging system.

Following the instructions of the Biospin extraction kit, PCR products were purified and detected by $1 \%$ agarose gel, then was cloned into the PMD 19-T vector at $16^{\circ} \mathrm{C}$ for $10 \mathrm{~h}$. The ligation products were transformed into the DH5 $\alpha$ competent cells; $100 \mu \mathrm{L}$ of transformed cells was spread on LB plates containing Amp, X-gal and IPTG; the plates were incubated for $16 \mathrm{~h}$ at $37^{\circ} \mathrm{C}$. Isolated Amp-resistant colonies were selected to inoculate LB broth, which contained Amp at $37^{\circ} \mathrm{C}$, and incubated on a shake bed overnight. The overnight products were used for PCR identification. Plasmid was collected using the plasmid collection method in molecular cloning, and then PCR identification was performed. Recombinant clones were sequenced by Shanghai Invitrogen Biotechnology Co LTD.

1.2.5 Fluorescent quantitative PCR analysis 
1.2.5.1 Florescent quantitative PCR Two microliters of cDNA each from $0 \mathrm{~h}, 8 \mathrm{~h}, 16 \mathrm{~h}$ and $24 \mathrm{~h}$ oocytes were pipetted into 96 wells of a microtiter plate for real time PCR in ABI7300. Twenty-five microliters for the reaction system: cDNA $2 \mu \mathrm{L}$, BMP15 or GAPDH forward primer, reverse primer $0.5 \mu \mathrm{L}$ (10 pmol), SYBR Premix Ex Taq $12.5 \mu \mathrm{L}$, ROX Reference Dye $2 \mu \mathrm{L}$, diluted by $\mathrm{ddH}_{2} \mathrm{O}$ to $25 \mu \mathrm{L}$. Each experimental sample was run in triplicate. Samples were treated at $95^{\circ} \mathrm{C}$ for $10 \mathrm{~s}$ followed by 40 cycles of amplification at $95^{\circ} \mathrm{C}$ for 5 $\mathrm{s}$ and $58^{\circ} \mathrm{C}$ for $31 \mathrm{~s}$. After the amplification, the melting curve was analyzed. No template controls, substituting cDNA for water were used in each run. BMP15 primer pair was above in 1.2.4, and the 260-bp fragment of rabbit BMP15 was obtained. To consider GAPDH as an appropriate reference gene, the primers were designed according to reference ( $\mathrm{Wu}, 2007)$. Forward primer: 5'-AAGGTCATCCACGACCA CTT-3', Reverse primer: 5'-AGGCCATGCCAGTGAGT T-3'. A 213-bp PCR fragment was expected to be amplified. All primers were synthesized by Shanghai Sangon Biological Engineering Technology \& Services Co Ltd.

1.2.5.2 Standard curve of florescent quantitative PCR Five microliters of cDNA from ovaries was diluted 1 in 5 , 5 times $(1,1: 5,1: 25,1: 125,1: 625,1: 3125), 2$ $\mu \mathrm{L}$ solution from each concentration was collected as a sample separately for making BMP15 and GAPDH gene standard curves. The slope of the standard curve was given in ABI software. The PCR efficiency (E) of BMP15 and GAPDH were calculated according to the equation: $\mathrm{E}=10^{-1 / \mathrm{S}}-1$.

1.2.6 Statistical analysis REST software was used (Yu et al, 2007) for analysis: $\mathrm{Ct}$ value for all samples and PCR efficiency of BMP15 and GAPDH were inputted in the corresponding interface. The expression ratio and statistical analyses were given by the software. The relative expression ratio $(\mathrm{R})$ of a target gene is calculated based on $\mathrm{E}$ and the $\mathrm{Ct}$ deviation of an unknown sample versus a control, and expressed in comparison to a reference gene. Ratio $=\left(\mathrm{E}_{\text {target }}\right)^{\triangle \mathrm{CTtarget}}$ (control-sample) $/\left(\mathrm{E}_{\text {reference }}\right) \triangle \mathrm{CT}$ ref (control-sample)

\section{Results}

\subsection{Amplification of rabbit BMP15 gene}

The expected fragment of the rabbit BMP15 gene was amplified from the total ovarian RNA (Fig. 1), the specificity of RT-PCR products was documented with gel electrophoresis and resulted in a single product with the desired length (Fig. 2). Approximately $260 \mathrm{bp}$ of partial rabbit BMP15 gene was obtained. No primerdimers were observed.

The sequencing result of the positive clones was a fragment of rabbit BMP15 gene with a length of $260 \mathrm{bp}$. The cDNA sequence was aligned with the BLAST program available on GenBank. The result demonstrated that the sequence was the coding region of the second exon of the BMP15 gene. This cloned rabbit BMP15 gene had a high homology with the reported animal BMP15 gene. The analysis showed the homology of this gene sequence with porcine (Sus scrofa), cow (Bos taurus), sheep (Ovis aries), goat (Capra hircus), human (Homo sapiens) and mouse (Mus musculus) were 90\%, $89 \%, 89 \%, 89 \%, 83 \%$ and $83 \%$. This sequence had been submitted to GenBank under accession number EU368755. The amino acid sequence of BMP15 gene was deduced according to the nucleotide sequence and comparison of the predicted sequence with those published of a typical BMP15 were performed by ClustalW software (Fig. 3).

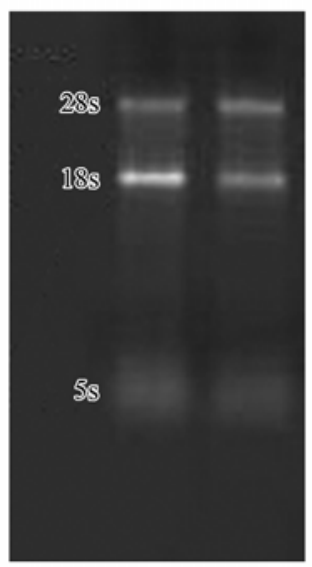

Fig. 1 Agarose gel electrophoresis of rabbit RNA

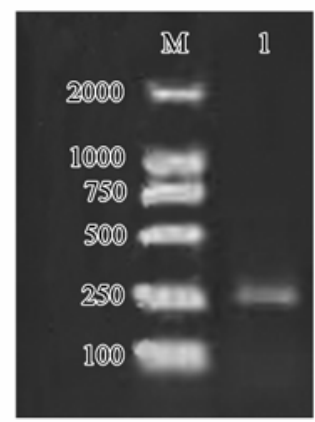

Fig. 2 Electrophoresis of rabbit BMP15gene PCR product M: Marker DL-2000; 1: products of PCR amplification. 


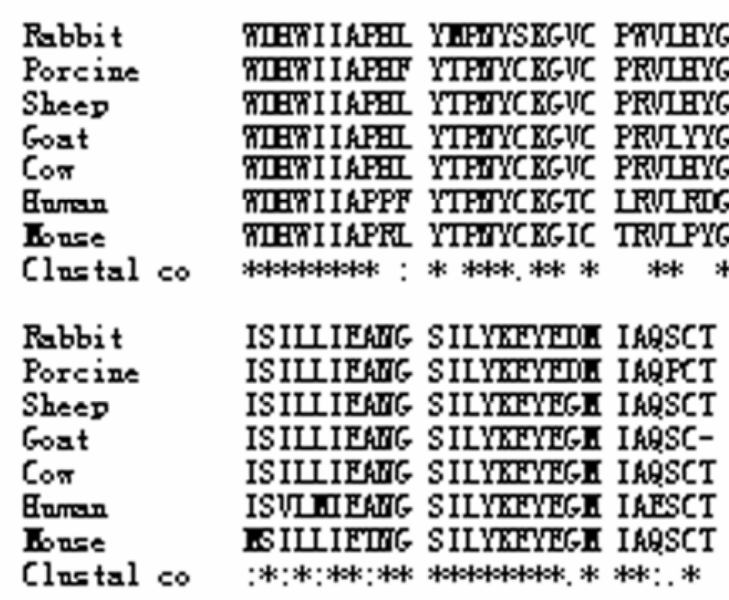

Fig. 3 Homologous comparison of partial amino acid sequences of BMP15 in different species

\subsection{Standard curve of florescent quantitative PCR}

Using the ovarian cDNA as a template, the standard curves of BMP15 and GAPDH gene were made from a series of progressive $1: 5$ dilutions. The correlation coefficient $r$ of the BMP15 and GAPDH were 0.995 and 0.998 , and the slopes were -3.231 and -3.38 respectively. The corresponding amplification efficiencies (E) of the BMP15 and GAPDH calculated from the equation were $103.9 \%$ and $98.4 \%$ respectively.

\subsection{Expression of BMP15 mRNA rabbit oocytes in vitro maturation}

Florescent quantitative PCR was to characterize the expression pattern of BMP15 mRNA in rabbit oocytes during maturation in vitro (Fig.4). The results revealed a dynamic change in the IVM process. Analysis of REST showed that the relative expression level of BMP15 mRNA in oocytes at $8 \mathrm{~h}$ was 0.884 times as the ones at 0 $\mathrm{h}$. There was no significant difference $(P>0.05)$ and they were both expressed at a low level. However, mRNA expression of BMP15 reached a peak at 16h, which was consistent with the expansion time of cumulus cells. The level was about 9.841-fold that of the $0 \mathrm{~h}$, there was a significant difference $(P<0.01)$, BMP15 mRNA declined at $24 \mathrm{~h}$ and still significantly differed from the $0 \mathrm{~h}$ $(P<0.05)$.

\section{Discussion}

BMP15, which is progressively expressed by oocytes of growing follicles throughout folliculogenesis, is a oocyte-secreted paracrine factor (McNatty et al, 2005). It can exert an effect on neighboring granulose cells, which in turn regulate oocyte development in vitro. According to previous studies, generally the BMP15 gene contains two exons, separated by a single intron.

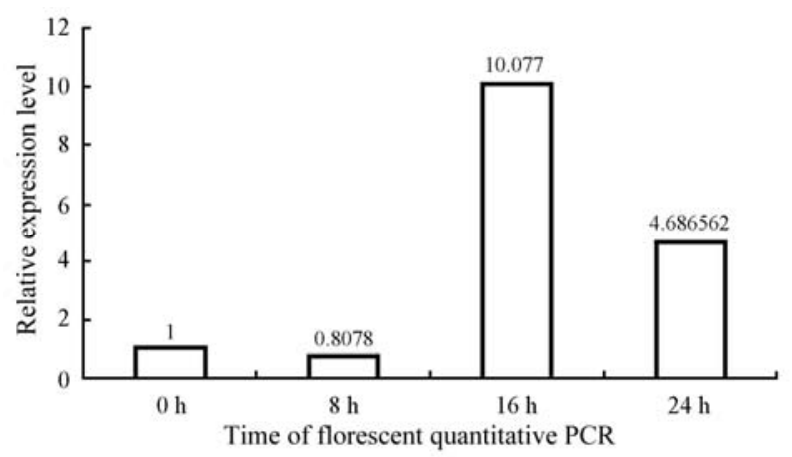

Fig. 4 mRNA expression of BMP15 in rabbit COCs under IVM cultivation

This research obtained partial cDNA sequences (260bp) of rabbit BMP15 gene by using RT-PCR and cloning. The blast analysis demonstrated the obtained fragment was part of a coding region of BMP15 gene, which has an overall similarity with corresponding nucleotides of porcine, cow, sheep, goat, human and mouse. Compared with reported animal BMP15 gene sequences, this predicted amino acid sequence was different from the above animals in 8, 7, 9, 9, 18 and 18 amino acids respectively. This research provides the possibility to successfully clone the full length cDNA sequence and is a foundation of polymorphism study of BMP15 gene between different rabbit varieties. Research has found that the Inverdale and Hanna mutations of BMP15 gene in ewes will directly influence follicular growth and development. Critical roles of BMP15 in female fertility have also been demonstrated in humans. Specifically, Pasquale et al (2004) identified a mutation of BMP15 in women that was related to hypergonadotropic ovarian failure due to ovarian dysgenesis. It was reported that BMP15 had great effects on ovulation rate and fertility in 
a dosage-sensitive manner; it may be the central player in the determination of ovulation quota. Consequently, this finding will bring great insights for further studies about the relationship between this gene and reproductive performance (e.g. litter size, ovulation rate) in rabbits.

In our investigation, BMP15 was expressed throughout oocyte maturation in vitro and the expression level peaked at $16 \mathrm{~h}$, which was distinctively higher than in other periods. At $16 \mathrm{~h}$ of oocyte IVM, cumulus expansion

\section{References:}

Dragovic RA, Ritter LJ, Schulz SJ, Amato F, Armstrong DT, Gilchrist RB. 2005. Role of oocyte-secreted growth differentiation factor 9 in the regulation of mouse cumulus expansion [J]. Endocrinology, 146: $2798-2806$.

Dube JL, Wang P, Elvin J, Lyons KM, Celeste AJ, Matzuk MM. 1998. The bone morphogenetic protein 15 gene is X-linked and expressed in oocytes[J]. Mol Endocrinol, 12 (12): 1809-1817.

Eppig JJ. 2001. Oocyte control of ovarian follicular development and function in mammals [J]. Reproduction, 122: 829-838.

Gilchrist RB, Ritter LJ, Armstrong DT. 2004. Oocyte-somatic cell interactions during follicle development in mammals[J]. Anim Reprod Sci, 82-83: 431-446.

He YQ, Chu MX, Wang JY, Fang L, Ye SC. 2006. Polymorphism on BMP15 as a candidate gene for prolificacy in six goat breeds [J]. Journal of Anhui Agricultural University, 33(1): 61-64.

Hou ZP, Yin YL, Huang RL, Li TJ, Zhang P. 2006. Study on cloning and sequencing of pig bone morphogenetic protein-15 coding sequence [J]. Journal of Guangxi Agric and Biol Science, 25(2): 91-95.

Hussein TS, Froiland DA, Amato F, Thompson JG, Gilchrist RB. 2005. Oocytes prevent cumulus cell apoptosis by maintaining a morphogenicparacrine gradient of bone morphogenetic proteins [J]. Cell Sci, 118: 5257-5268.

Li HK, Kuo TY, Yang HS, Chen LR, Lie SSL, Huang HW. 2008. Differential gene expression of bone morphogenetic protein 15 and growth differentiation factor 9 during in vitro maturation of porcine oocytes and early embryos [J]. Anim Reprod Sci, 103(3-4): 312-22.

Liao WX, Moore RK, Otsuka F, Shimasaki S. 2003. Effect of intracellular interactions on the processing and secretion of bone morphogenetic protein-15 (BMP-15) and growth and began; this suggested that BMP15 may have had a great effect in cumulus expansion, corresponding with the research results in porcine ( $\mathrm{Li}$ et al, 2008), and mice (Pasquale et al, 2004), but differing from the studies in bovine. The underlying cause of the differences may be due to the different functions of BMP15 gene in poly-ovulatory animals (e.g. mouse, rabbit) and mono-ovulatory animals (e.g. cow).

differentiaton factor-9: implication of the aberrant ovarian phenotype of BMP-15 mutant sheep [J]. Biol Chem, 278: 3713-3719.

McNatty KP, Juengel JL, Wilson T, Galloway SM, Davis GH, Hudson NL, Moelle CM, Reader KL, Laitinen MP, Groome NP, Sawyer HR, Ritvos O. 2003. Oocyte-derived growth factors and ovulation rate in sheep [J]. Reproduction, 61: 339-351.

McNatty KP, Jennifer JL, Karen LR, Lun S, Myllymaa S, Lawrence SB, Western A, Meerasahib MF, Mottershead DG, Groome NP, Ritvos O, Laitinen MPE. 2005. Bone morphogenetic protein 15 and growth differentiation factor 9 co-operate to regulate granulosa cell function [J]. Reprod, 129: 473-480.

Pasquale ED, Beck-Peccoz P, Persani L. 2004. Hypergonadotropic ovarian failure associated with an inherited mutation of human bone morphogenetic protein-15 (BMP15) gene [J]. Am J Hum Genet, 75(1): 106-111.

Prochazka R, Nemcova L, Nagyova E, Kanka J. 2004. Expression of growth differentiation factor 9 messenger RNA in porcine growing and preovulatory ovarian follicles [J]. Biol Reprod, 71: 1290-1295.

Wu YL. 2007. Collateral disease theory and its clinical study [M]. Beijing: Science and Technique Press.

Yan C, Wang P, DeMayo J, DeMayo FJ, Elvin JA, Carino C,Prasad SV, Skinner SS, Dunbar BS, Dube JL, Celeste AJ, Matzuk MM. 2001. Synergistic roles of bone morphogenetic protein 15 and growth differentiation factor 9 in ovarian function [J]. Mol Endocrinol, 15: 854-866.

Yu L, Liu JP, Yang LQ, Zhang RL, Ye XM, Cheng JQ. 2007. Quantitative Analysis of Real-Time PCR Expression Production by REST and $2^{(-\Delta \Delta C T)}[\mathrm{J}]$. Journal of Tropical Medicine, 10(7): 956-958. 